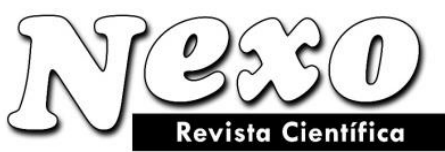

Vol. 34, No. 01, pp. 448-456/Marzo 2021

\title{
Housing market: the concept, features, and role in the socio-economic development of the state
}

\section{Mercado de la vivienda: concepto, características y papel en el desarrollo socioeconómico del estado}

\author{
Elena Vladimirovna Litvinova, Veronika Andreevna Danilova \\ Russian State University of Tourism and Service, Moscow, Russian Federation. \\ * litvinova.el.v@yandex.ru
}

(recibido/received: 12-November-2020; aceptado/accepted: 07-January-2021)

\begin{abstract}
The research is based on the dialectical method which predetermines the study of phenomena in their constant development and interrelation. Besides, the article uses a systematic approach, methods of comparative, statistical, and graphical analysis. The novelty of the present article lies in the proposal for adjustments to the calculation of the housing affordability index in the Russian Federation (RF), as well as the proposed typology of housing in the RF taking into account lifestyles of various categories of the population. The authors have developed the version of the content of the infrastructure of the commercial rental of housing, which defines it as a system of material and information conditions ensuring stable and efficient production of housing services (housing rental services) through the operation of both commercial apartment buildings and other objects of the rental housing market. A system of measures is proposed to remove the rental housing market from the shadow and its further development including that of the commercial apartment building business.
\end{abstract}

Keywords: Housing Affordability; Housing Construction, Mortgage; Housing Policy; State Support.

\section{RESUMEN}

La investigación se basa en el método dialéctico que predetermina el estudio de los fenómenos en su constante desarrollo e interrelación. Además, el artículo utiliza un enfoque sistemático, métodos de análisis comparativo, estadístico y gráfico. La novedad del presente artículo radica en la propuesta de ajustes en el cálculo del índice de asequibilidad de la vivienda en la Federación de Rusia (RF), así como en la tipología de vivienda propuesta en RF teniendo en cuenta los estilos de vida de diversas categorías de la población. Los autores han desarrollado la versión del contenido de la infraestructura del alquiler comercial de vivienda, que la define como un sistema de condiciones materiales e informativas que aseguran la producción estable y eficiente de los servicios de vivienda (servicios de alquiler de vivienda) a través de la operación de ambos departamentos comerciales. edificios y otros objetos del mercado de viviendas de alquiler. Se propone un sistema de medidas para sacar de la sombra el mercado de la vivienda en alquiler y su desarrollo posterior, incluido el de la construcción de viviendas comerciales.

Palabras clave: Asequibilidad de la vivienda; Construcción de Vivienda, Hipoteca; Política de vivienda; Apoyo estatal. 


\section{INTRODUCTION}

The housing market is the most important segment of the national economy, while the solution to the housing problem is the main task of the priority national project "Housing and Urban Environment". Today, objectively, there is a huge need for new housing, to meet the needs of the population to change places of residence, and to improve housing conditions (Bobyleva, 2016).

The solution to the housing problem is unthinkable without creating transparent market relations in each segment of the real estate market and its associated markets. The state, complementing the market, should contribute to the creation of an optimal structure of the housing stock. The development of rental relations in the housing sector can and should become one of the main directions in ensuring adequate housing conditions, and have huge impact on accelerating economic growth. It is rental housing payments in the markets of developed countries that are one of the significant sources of financing for new construction.

\section{METHODS}

The present research aims to develop theoretical bases of the mechanism of forming the market of accessible housing, and to provide practical recommendations on its functioning, taking into account features of socio-economic development of the country.

The research was based on the dialectical method, which determined the study of phenomena in their constant development and interrelation. Besides, the article used a systematic approach, as well as methods of comparative analysis.

\section{RESULTS AND DISCUSSION}

The existence and development of the housing market are due to the need of the population to improve housing conditions and an acute shortage of housing. Today it is the most developed real estate sector.

Real estate is the most important component of the country's economy and has significant impact on the economic, social, and political development of the territory. It is the real estate as a material good that has a material character that forms the basis of the well-being of both societies in general and its citizens, in particular, being a category of wealth (Averin, Babich, Berestova, 2016; Gaponenko, 2001).

According to article 130 of the Civil Code of the RF, immovable things (immovable property, real estate) include land plots, subsurface areas, and everything that is firmly connected with the land, that is, objects that cannot be moved without disproportionate damage to their purpose, including forests, perennial plantings, buildings, structures, as well as objects of unfinished construction. This is the so-called real estate by origin (Duborkina et al., 2018; Litvinova, Litvinov, 2009; Panova, 2012).

The present work considers only residential premises, which, according to article 16 of the Housing Code of the RF, include houses, apartments, and rooms as part of houses and apartments. Actually, these three objects are the subjects of transactions in the housing market, that is, goods intended for sale, exchange, or other commercialization.

In the classical sense, the market is a set of socio-economic relations in the field of distribution and exchange, through which the sale of goods is carried out. A market is a form of communication between economic entities, whose relations are built based on the private property institution (Romanovich, 2014; Khavanova, Litvinova, 2015; Bokareva et al., 2018). 
The housing market is a real estate circulation sector intended for the residence of citizens, regulated by civil legislation, which is expressed in the interaction of sellers, buyers, and third parties with each other to make transactions with residential premises. The real estate market is divided into areas based on the purpose of real estate and its attractiveness to various market players.

Depending on the legal framework, financing conditions, and forms of ownership, the real estate market is constantly changing and is unique for each country, region, and city.

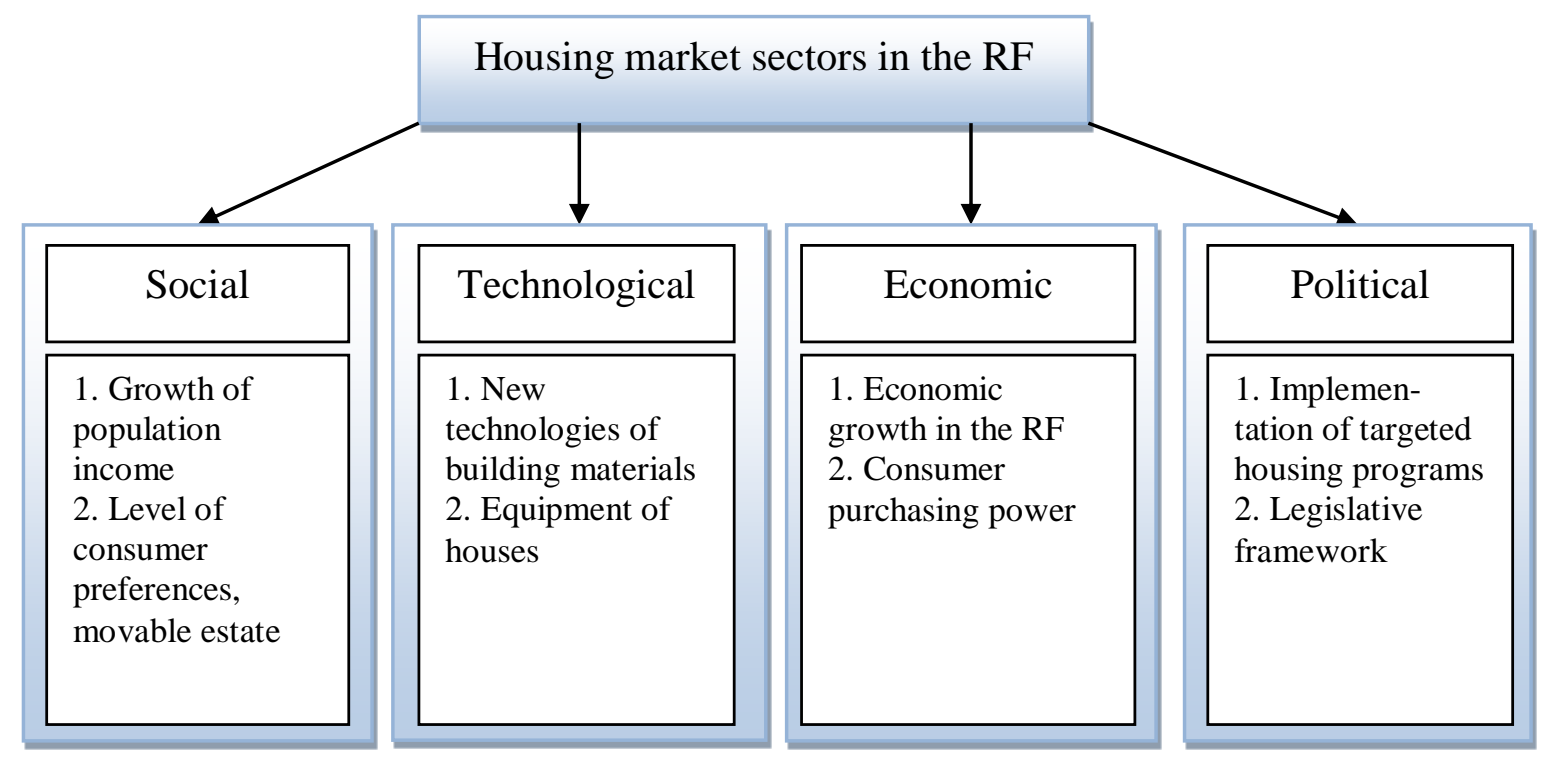

Figure 1. The housing market sectors in the RF (Pirozhenko et al., 2018; Bokareva et al., 2018; 2019; Morozova et al., 2016)

Each sector of the housing market has an equally important impact on meeting housing needs because all areas interact with each other. The division of the real estate market into separate segments is carried out according to the prevailing needs of market participants.

The proposed form of the housing market segmentation involves distinguishing two groups of segments:

- social segment, i.e. housing provided for social hiring;

- market segments, i.e. the rental housing segment, the nonprofit housing segment (cooperative and individual housing), the commercial housing segment (nonstimulated housing market segment).

Table 1. Housing market segments (Gaponenko, 2001)

\begin{tabular}{|l|l|c|}
\hline Housing market segment & Groups of citizens by income level & $\begin{array}{l}\text { Forms of state support } \\
\text { for citizens }\end{array}$ \\
\hline $\begin{array}{l}\text { The social housing segment } \\
\text { (social segment) }\end{array}$ & $\begin{array}{l}\text { Low-income citizens and citizens in } \\
\text { need of social support measures } \\
\text { when renting municipal housing }\end{array}$ & $\begin{array}{l}\text { Providing housing on the } \\
\text { terms of social hiring. } \\
\text { Differentiating hiring fees } \\
\text { taking into account the } \\
\text { income of tenant citizens }\end{array}$ \\
\hline $\begin{array}{l}\text { The rental housing segment } \\
\text { (market segment) }\end{array}$ & $\begin{array}{l}\text { Citizens, whose income allows them } \\
\text { to pay for the rental of housing but } \\
\text { does not allow purchasing housing as } \\
\text { property, even with the use of }\end{array}$ & $\begin{array}{l}\text { Providing a tax deduction for } \\
\text { personal income tax in part of } \\
\text { the amount spent on housing } \\
\text { rental payments }\end{array}$ \\
\hline
\end{tabular}




\begin{tabular}{|l|l|l|}
\hline & $\begin{array}{l}\text { savings and credit mechanisms, as } \\
\text { well as state support mechanisms. }\end{array}$ & \\
\hline $\begin{array}{l}\text { Noncommercial housing } \\
\text { construction segment } \\
\text { (cooperative and individual } \\
\text { housing) } \\
\text { (market segment) }\end{array}$ & $\begin{array}{l}\text { Citizens, whose income allows them } \\
\text { to build and purchase housing in the } \\
\text { property using savings and credit } \\
\text { mechanisms, as well as mechanisms } \\
\text { of state support but insufficient to } \\
\text { purchase housing without the use of } \\
\text { such mechanisms. }\end{array}$ & $\begin{array}{l}\text { Providing state targeted } \\
\text { support for the purchase and } \\
\text { construction of housing. } \\
\text { Providing a tax deduction for } \\
\text { personal income tax in part of } \\
\text { the amount spent on the } \\
\text { purchase of housing } \\
\text { ownership or housing } \\
\text { construction }\end{array}$ \\
\hline $\begin{array}{l}\text { Commercial housing } \\
\text { construction segment } \\
\begin{array}{l}\text { a nonstimulated segment } \\
\text { of the housing market) } \\
\text { (market segment) }\end{array}\end{array}$ & $\begin{array}{l}\text { Citizens whose income allows them } \\
\text { to purchase housing without using } \\
\text { state support mechanisms. }\end{array}$ & $\begin{array}{l}\text { Providing a tax deduction for } \\
\text { personal income tax in part of } \\
\text { the amount spent on the } \\
\text { purchase of housing } \\
\text { ownership or housing } \\
\text { construction }\end{array}$ \\
\hline
\end{tabular}

In each market segment, one can talk about the presence of two components:

- primary component, which characterizes the appearance of real estate as a commodity on the market; the state, represented by federal, regional, and local authorities, currently acts as the main seller of real estate;

- secondary component, which involves a large number of sellers and buyers (individuals and legal entities).

Meeting the demand in market segments and that in the social segment, as well as the growing citizens' incomes result in a significant overflow of demand from segment to segment. Consequently, demand in market segments constantly increases (Abadzhidi et al., 2010; Averin et al., 2016; Litvinova, Litvinov, 2009).

With a strong imbalance between supply and demand caused by small construction volumes, as well as a significant difference in the income of different categories of the population, it is necessary to provide incentives for the development of various segments, taking into account the solvency of all categories of citizens, using special regulatory mechanisms (incentives) of both demand and supply in each of the segments of the housing market.

The development of the market mechanism elements of the real estate market depends on a large number of factors, among which price, demand, and supply are in the first place.

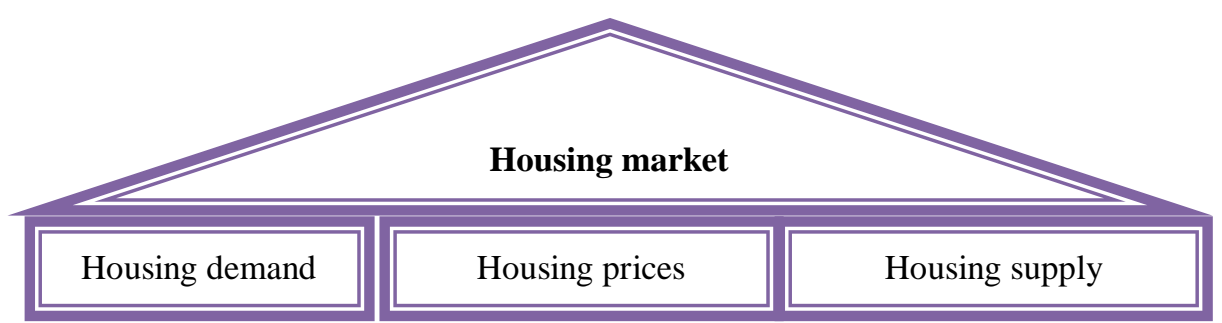

Figure 2. Housing market elements (Averin, Babich, Berestova, 2016; Bobyleva, 2016)

The demand for housing facilities and generated housing services is determined through the amount of housing that consumers want to buy, that is, it depends on peculiarities induced by the financial capability of consumers, the cost of housing, price of other goods and services, income, and individual preferences. 
Demand for housing and housing services is inversely proportional to prices and directly proportional to income levels. In the short term, this demand is quite elastic with regard to prices.

The change in demand depends on factors, such as:

1) buyers' consumer choice or preferences;

2) the number of buyers;

3) the level of buyers' income;

4) prices for related products (interchangeables);

5) consumer expectations regarding future prices and revenues.

The supply of housing and housing services limits the demand function and represents the amount of housing that a consumer can purchase on the market at the current price level. Factors affecting the supply of housing are the level of gross investment in construction, maintenance of housing stock, and the rate of its depreciation (disposal). Gross investment is directed to the construction, reconstruction, and repair of the existing housing stock. As part of the gross investment, the so-called net investments can be distinguished, which represent the difference between gross investment in housing and the level of its losses (depreciation, disposal). Only a small amount of new housing enters the market every year, and the housing stock will only change in the long term. An increase in the cost of maintenance, reconstruction, and modernization of housing should lead to an increase in the quality of housing services offered, and, as a result, to an increase in their cost. Rising prices in the housing market make it profitable to spend on its maintenance and new construction. With low housing prices, it often becomes unprofitable to maintain a housing facility. At that, the degree and speed of its deterioration increases. If the level of current housing prices is equal to the cost of construction then no net investment can be obtained (Pirozhenko et al., 2018; Platonova, Zvorykina, 2008; Romanovich, 2014).

The formation of housing supply is primarily related to the volume and quality of available housing (available housing stock and its condition) and the capital market (the level of capitalization of real estate), which determines the prices of housing stock and its production volume. At the same time, the supply of housing stock is closely related to the demand generated in the housing market through housing costs and is dictated by the needs of the population in housing, and the level of income from the use of the real estate. The population's need for housing is determined primarily by demographic and general economic conditions, as well as the level of income of the population.

Construction, being subject to the internal connections of the system, is the housing sector element, through which a balance is established between the main parameters of the housing market and the housing services market. The housing market functioning mechanism is determined by its main parameters, such as housing costs, price, construction, and housing stock, formed under the influence of supply and demand factors.

A special role in the housing market belongs to the state and local self-government bodies, which not only perform certain functions as market participants but also carry out legislative and statutory regulation of the processes taking place in the market.

Today, the solution to the housing problems of the population of Russia in terms of importance for the state comes to the fore. Comfortable housing is important for recreation, work, and creating a family. Meanwhile, even the current increase in income does not always allow people to buy housing and improve 
its quality. This results in the low mobility of the population, which does not allow people to move around the country in search of a suitable job.

Housing is the most important sector of the economy, influencing the overall economic well-being of the country.

State housing policy is an important part of the socio-economic transformation in Russia and one of the main activity areas of state authorities. In the course of the transition to a market economy, the content of this activity consists in reforming the housing sector, whose central place belongs to the housing reform. The economic and political factors that lead to direct government intervention in the housing system often outweigh the social ones. Housing policy is an important means of public participation in solving the housing problem.

Housing affordability reflects the ratio of real estate prices and the financial capabilities of the population. In Russia, even though the policy of increasing housing affordability has been conducted for almost 10 years, there is no clear understanding of what affordable housing is and for whom it should be affordable. Based on the research results of the Public Opinion Foundation which has surveyed the population concerning the issue of what affordable housing is, it can be concluded that the population does not believe in the concept of affordable housing and does not understand clearly what is included in its concept.

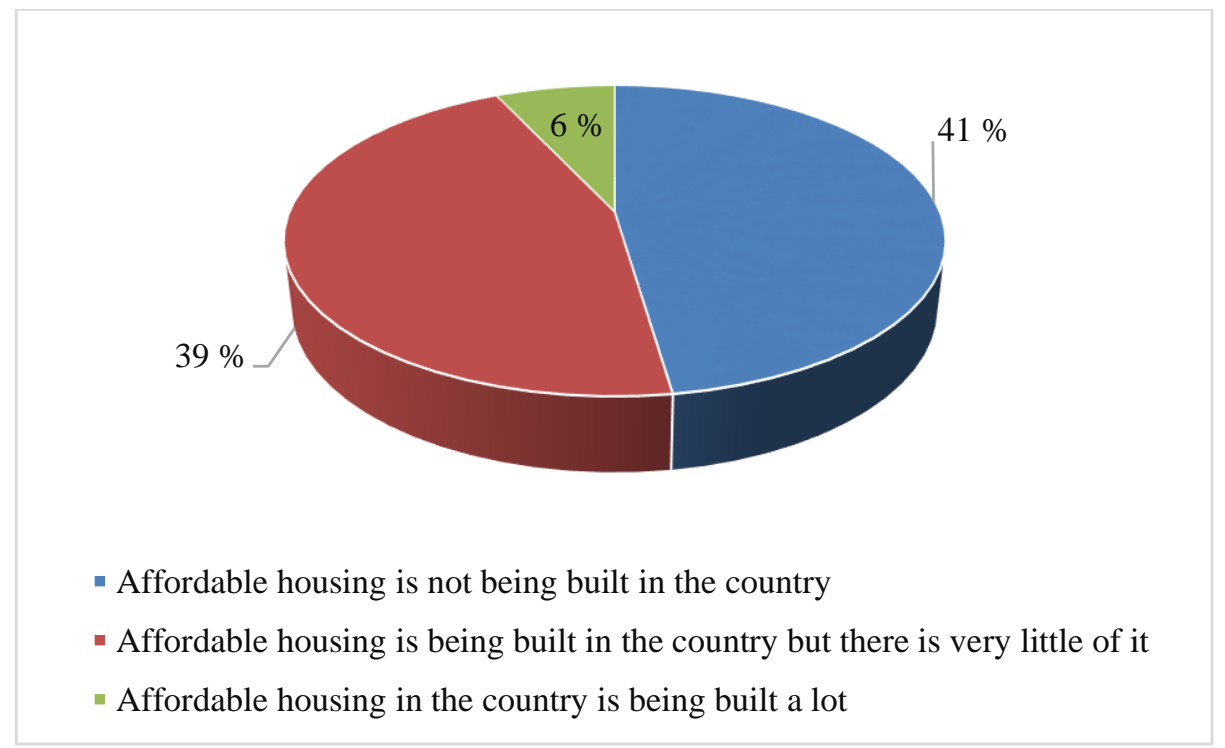

Figure 3. Public opinion on the construction of affordable housing in the RF, \%

The concepts of housing affordability and affordable housing should not only be based on calculated values but also be understandable to the population.

In Russia, due to the lack of data on median incomes and median housing prices, the housing affordability index or housing price to income ratio (hereinafter referred to as HPIR) according to the Housing Federal Target Program is calculated based on the following indicators: the average price per square meter (sq. $\mathrm{m}$ ) of housing, the average per capita monetary income multiplied by three (a family of three people), and the social standard of housing area corresponding to this family size which is $54 \mathrm{sq}$. $\mathrm{m}$. This indicator does not take into account consumption expenditures, as well as the possibility of purchasing housing by taking out mortgage loans, and thus it only reflects the current ratio between average housing prices and average incomes (Bokareva et al., 2019). 
In its economic essence, this indicator characterizes only one of the factors of housing affordability, namely, the ratio of prices in the housing market and the level of income of the population. For the most effective solution to the housing problem, it seems appropriate to propose certain changes to the calculations of the housing affordability index in the RF.

Below are the calculations of the level of availability in the housing market of a standard apartment of 54 sq. $\mathrm{m}$ for a family of three people.

The housing affordability index has been calculated since 1998 using the following formula:

$$
\mathrm{A}=(\mathrm{C} * 54) /(\mathrm{I} * 3 * 12 * \mathrm{~S})
$$

Where $C$ is the average cost per sq. $\mathrm{m}$ of housing; $I$ is the average per capita monthly income; 54 means the area of a conditional apartment, sq. m; 3 means the number of household members, person; 12 means the number of months in a year; $S$ is the saving ratio in unit fraction.

The average cost per sq. $\mathrm{m}$ of housing $C$ can include also the total a

mount of interest on the mortgage loan when determining the conditional term of the loan and the interest rate. The savings ratio $S$ in this case is essentially a fraction of the monthly income that a citizen can spend on housing, provided that all his basic needs are met.

In its economic essence, this indicator characterizes only one of the factors of housing affordability, namely the ratio of prices in the housing market and the level of income of the population (Gaponenko, 2001).

In international practice, the term housing affordability means the possibility of purchasing housing by the consumer. The main impact on housing affordability is the cost of housing, the cost of a mortgage loan (interest rate), other conditions of mortgage lending, and total household income, as well as factors, such as property tax, the fee for housing, and utility services, and insurance payments.

\section{CONCLUSIONS}

Housing affordability is a comprehensive assessment of the social orientation of the housing market. Housing affordability directly affects the state of demographic indicators of the country, and the growth of its population. Ensuring housing affordability opens up the possibility of an effective migration policy since long waiting lists for housing have a serious adverse impact on the mobility of the labor force and the unemployment rate linking citizens to the place of housing registration, and preventing the free movement of labor resources within the economic space of the country (Abadzhidi et al., 2010).

For Russia, given its geographical scale, the solution to this problem is of paramount importance. In particular, this is the key to solving the problem of acute shortage of workers in regions of the main resource base concentration, such as Siberia, the Far East, and several other regions, because the state cannot provide citizens with affordable housing in these regions. Housing affordability is a very painful problem. If it is not mitigated, it will remain a serious bottleneck of economic growth and, moreover, a source of social tension in society.

Housing policy is an important means of public involvement in solving the housing problem. The optimal strategy of the state in the housing market is to create and promote the most favorable living conditions for socially and economically active segments of the population.

\section{REFERENCES}


Abadzhidi, A.G., Morozov, V.Yu., Shestakova, S.V., Shestakov, V.A. (2010). Monitoring v sisteme okazaniya gosudarstvennyh i municipal'nyh uslug [Monitoring in the system of rendering state and municipal services]: Monograph. Moscow.

Averin, A.N., Babich, A.M., Berestova, L.I. (2016). Social'naya politika: Enciklopediya [Social policy: Encyclopedia]. Moscow: Alpha-Press.

Bobyleva, A.Z. (2016). K razrabotke koncepcii perekhoda gosudarstvennyh organizacij na «upravlenie po rezul'tatam» [On the development of the concept of state organizations transition to results-based management]. Public Administration. Electronic Bulletin of the Federal State University of Moscow State University, 9. Retrieved from: http://www.e-journal.spa.msu.ru/9 2006Bobyleva.html

Bokareva, E.V., Silaeva, A.A., Borisova, O.N., Sokolova, A.P. (2018). Analysis of the world and Russian e-commerce market: Development trends and challenges. International Journal of Engineering and Technology (UAE), 7(4.38), 387-392.

Bokareva, E.V., Silaeva, A.A., Danilova, V.A., Romanovich, V.K., Boboshko, V.I., Boboshko, N.M. (2019). Development of a business strategy based on project management. International Journal of Engineering and Advanced Technology, 8(5), 1020-1024.

Duborkina, I.A., Bokareva, E.V., Yudina, E.V., Panova, A.G., Sokolova, A.P., Levshenkova, A.A. (2018). Prakticheskoe primenenie marketinga na predpriyatii zhilishchno-kommunal'nogo hozyajstva [Practical application of marketing at the housing and communal services enterprise]. Economics and Entrepreneurship, 12(101), 716-719.

Gaponenko, A.G. (2001). Strategiya social'no-ekonomicheskogo razvitiya: strana, region, gorod [Socioeconomic development strategy: Country, region, city]: textbook. Moscow: RAGS Publishing House.

Khavanova, N. V., Litvinova, E.V. (2015). Puti povysheniya effektivnosti vzyskaniya zadolzhennosti s grazhdan za uslugi $\mathrm{v}$ sfere zhilishchno-kommunal'nogo hozyajstva [Ways to increase the efficiency of debt collection from citizens for housing and communal services]. Service in Russia and Abroad, 9, 3(59), 181-194.

Litvinova, T.P., Litvinov, E.V. (2009). Dohodnye doma kak instrument realizacii nacional'nogo proekta "dostupnoe i komfortnoe zhil'e grazhdanam Rossii" [Commercial apartment buildings as a tool of the national project "Affordable and comfortable housing to citizens of Russia"]. Service Plus, 2, 98-104.

Morozova, L.S., Morozov, V.Y., Khavanova, N.V., Lustina, T.N., Panova, A.G. (2016). Approach to evaluating personnel loyalty in the context of streamlining the company's human resources policy. Indian Journal of Science and Technology, 9(12), 895-926.

Panova, A.G. (2012). Sovershenstvovanie organizacii predostavleniya municipal'nyh uslug byudzhetnymi uchrezhdeniyami [Improving the organization of providing municipal services by the budgetary institutions]: Ph.D. thesis in economic sciences. Moscow: Russian State University of Tourism and Service.

Pirozhenko, N.T., Bokareva, E.V., Yudina, E.V., Podsevalova, E.N., Duborkina, I.A., and Sokolova, A.P. (2018). Upravlenie assimetrichnoj informaciej i ee rol' v vybore struktury kapitala [Management of asymmetric information and its role in the choice of the capital structure]. Economics and Entrepreneurship, 9(98), 86-90. 
Platonova, N.A., Zvorykina, T.I. (2008). Tekhnicheskoe regulirovanie: sfera uslug. [Technical regulation: Service sector]. Educational and Methodological Association of Universities of the Russian Federation. Moscow: Alfa-M.

Romanovich, V.K. (2014). Loyal'nost' potrebitelej kak faktor rynochnogo razvitiya torgovyh predpriyatij [Loyalty of consumers as a factor of market development of trade enterprises]. Proceedings of the international science-to-practice conference in the framework of the annual Chayanov readings "Innovations and modern technologies in the cooperative sector of the economy". The Russian University of Cooperation. 